\title{
PERLINDUNGAN HUKUM TERHADAP PENERIMA LISENSI PATEN DALAM ALIH TEKNOLOGI
}

\author{
Kadek Devi Arta Adnyani, I Nyoman Putu Budiartha, Ni Made Puspasutari Ujianti \\ Fakultas Hukum Universitas Warmadewa, Denpasar - Bali, Indonesia
}

\begin{abstract}
Abstrak
Lisensi merupakan kontrak di antara pemberi lisensi (licencor) dan pihak penerima lisensi (licencee). Dalam prosesnya, pemberi lisensi dengan suatu pembayaran dan dalam situasi tertentu memberikan izin kepada pihak penerima lisensi untuk mempergunakan suatu kekayaan intelektualnya (intellectual property rights). Terkait jenis-jenis lisensi, menurut Lee dan Davidson dibedakan menjadi 2 (dua) jenis lisensi, yaitu exclusive dan non-exclusive licenses. Perjanjian lisensi paten pada dasarnya tunduk dan mengacu pada ketentuan perjanjian yang dianut oleh Negara Indonesia pada KUH-Per. Pada jaman sekarang ini lisensi yang dituangkan dalam perjanjian mempunyai bentuk perjanjian baku atau standard contract. Kajian ini menelaah perjanjian lisensi paten menurut hukum positif di Indonesia dan perlindungan hukum terhadap penerima lisensi paten dalam penggunaan klausul kontrak baku. Pencapaian tujuan ini dilakuksan menggunakan metode penelitian hukum normative. Hasil analisis menunjukkan dalam suatu perjanjian lisensi, karena menggunakan suatu kontrak baku, berpotensi membawa ketidakseimbangan para pihak karena beberapa perjanjian pemberi lisensi (lisensor) menggunakan klausul-klausul yang dapat merugikan penerima lisensi (licencee). Perlindungan hukum represif digunakan jika suatu perjanjian lisensi dengan standard contract dipergunakan oleh pemberi lisensi paten (licencor) kepada penerima lisensi paten (licencee). Jika melanggar suatu syarat subjektif dalam pembuatan perjanjian lisensi paten akan menimbulkan akibat hukum berupa dapat dibatalkan (vernietigbaarheid), sedangkan apabila melanggar suatu syarat objektif, akan menimbulkan akibat hukum dalam bentuk batal demi hukum (neitigbaarheid).
\end{abstract}

Kata Kunci: Alih Teknologi; Kontrak Baku; Ketidak Seimbangan Kedudukan; Lisensi

\begin{abstract}
License represents the contract between the licensor and the licensee. In its process, the licensor with a payment and in certain circumstances lends permission to the licensee to use an intellectual property rights. Regarding the types of licenses, according to Lee and Davidson, they are divided into two types, exclusive and Nonexclusive licenses. Patent licensing agreements are basically subject to and refer to the provisions of the agreement adopted by the Indonesian State in the Indonesian Civil Code. In this day and age the licenses set forth in the agreement have the form of a standard agreement or standard contract. This study examines patent licensing agreements according to positive law in Indonesia and legal protection for patent license recipient in the use of standard contract clauses. To achieve these goals, the study was carried out using normative legal research method. The analysis shows that in a licensing agreement, since it makes use of a standard contract, it has the potential to bring an imbalance of the parties because some licensing agreements (licensors) use clauses that can harm the licensee. Repressive legal protection is used if a license agreement with a standard contract is used by the licensor of a patent (licensor) to the recipient of a patent license (licensee). If violating a subjective condition in making a patent license agreement, itwill result in a legal effect in the form of irrevocable (vernietigbaarheid), whereas if it violates an objective condition, it will cause legal consequences in the form of null and void (neitigbaarheid).
\end{abstract}

Keywords: Technology Transfer; Standard Contract; Imbalance; Licence

\section{PENDAHULUAN}

Teknologi memegang peranan yang sangat penting dalam dimensi pembangunan ekonomi global dewasa ini. Teknologi telah merasuk kedalam segala sendi kehidupan masyarakat termasuk untuk Negara berkembang seperti Indonesia terlebih lagi pada Era Revolusi Industri 4.0. Sebagai Negara berkembang, industrialisasi merupakan tujuan utama untuk dapat mencapai tingkat kesejahteraan yang lebih tinggi bagi rakyatnya. Industrialisasi memerlukan adanya modal atau investasi yang besar. Maka 
penanaman modal baik dari dalam negeri maupun penanaman modal asing menjadi sangat penting demi pembangunan nasional. Dengan adanya penanaman modal asing, diharapkan investor tertarik menanamkan modal tidak hanya membawa modalnya namun juga ilmu pengetahuan dan teknologi, keahlian dan keterampilan di berbagai bidang termasuk manajemen berorganisasi dan manajemen pemasaran (Udiana, 2011). Sebagai contoh dalam bidang pariwisata, pariwisata merupakan salah satu yang tercepat perkembangannya di dunia serta sumber utama pendapatan devisa dan lapangan kerja bagi banyak negara berkembang.

Di Indonesia, perkembangan pariwisata di indikasikan dengan peningkatan jumlah kunjungan wisatawan dimana kunjungan wisatawan tersebut sangat ditentukan oleh fasilitas penunjang yang tersedia baik secara kapasitas jumlah dan juga kualitas serta kemampuan sumber daya manusianya dalam mengelola dan memberikan pelayanan terbaik untuk para wisatawan. Dapat dicontohkan dengan suatu wilayah yang menjadi tujuan objek wisata memerlukan fasilitas penginapan yang memiliki pelayanan yang profesional, tranportasi yang dapat menunjang, sehingga wilayah yang menjadi tujuan wisata tersebut mudah untuk dikunjungi dan untuk mencapai tujuan tersebut maka dibutuhkan peranan dari pemerintah, swasta ataupun masyarakat (Julianto \& Marta, 2019). Dengan semakin berkembangnya pariwisata di Indonesia dan juga semakin banyaknya peluang yang ada dalam negara pariwisata diharapkan menarik pula minat para penanam modal asing maupun penanam modal dalam negeri untuk melakukan penanaman modal.

Masuknya penanam modal asing ke Indonesia dengan membawa teknologi-teknologi canggih ke dalam negeri dapat menguntungkan Indonesia karena adanya suatu program pengalihan teknologi. Pengalihan suatu teknologi menurut UNINDO adalah memberikan peluang dua hal yaitu peralatan penciptaan suatu barang yang satu tahap lebih maju dan pengawasan atas pertambahan barang (supply), pengawasan tidak hanya memiliki arti controlling terhadap suatu teknologi. Pengaturan tentang alih teknologi perlu mendapatkan perhatian guna datangnya suatu teknologi dari luar Negara ke Negara Indonesia, apakah melalui penanaman modal asing atau kerjasama perjanjian lisensi.

Perkembangan lisensi Paten diperkirakan akan selalu berkembang sangat pesat di waktu yang akan datang seiring dengan keperluan dengan adanya teknologi. Hal tersebut menyebabkan perlunya suatu perjanjian lisensi dengan pemilik hak paten dari luar Negara Indonesia dalam suatu program alih teknologi yang di lakukan oleh Indonesia terkait dengan penanaman modal asing. Akan tetapi, perjanjian lisensi paten yang diciptakan memiliki potensi menimbulkan adanya ketimpangan posisi para pihak yaitu penerima lisensi (licencee) dan pemberi lisensi (licensor), mengingat persyaratan pengalihan teknologi (term of condition) akan ditentukan secara sepihak oleh Licencor, oleh sebab itu munculnya ketentuan atau pasal tentang restrictive business practice atau yang sering kita sebut sebagai praktek bisnis terlarang. Ketentuan ini timbul secara terbuka di pasal-pasal perjanjian pengalihan teknologi. Mengingat tidak adanya suatu batasan pasti terkait perjanjian lisensi paten terhadap pengalihan teknologi yang pada dasarnya di atur dalam suatu perundang-undangan di Indonesia dan juga karena adanya suatu asas kebebasan berkontrak yang di atur dalam Kitab UndangUndang Hukum Perdata yang selanjutnya disebut KUH-Perdata. Hal tersebut menyebabkan semakin lemahnya kedudukan pihak penerima lisensi paten.

Indonesia memerlukan aturan ataupun batasan-batasan yang sangat jelas terhadap suatu perjanjian lisensi paten dan perlindungan hukum dalam pengalihan teknologi yang akan berlangsung. Dalam pembuatan perjanjian linsensi berpedoman pada asas-asas hukum kontrak yang dimana terdapat 5 (lima) asas yang dikenal menurut hukum perjanjian. Kelima asas itu yaitu: asas kebebasan berkontrak (freedom of contract), asas konsensualisme (concsensualism), asas kepastian hukum (pacta sunt servanda), asas itikad baik (good faith), dan asas kepribadian (personality) (Muhtarom, 2014). Dalam praktiknya asas kebebasan berkontrak (freedom of contract) inilah yang digunakan oleh pemegang lisensi untuk membuat perjanjian lisensi dimana sering kali perjanjian lisensi tersebut merupakan perjanjian baku. Dengan adanya perjanjian baku (standard contract) ini membuat kedudukan penerima lisensi paten lemah dan oleh karena kebutuhan yang mendesak (emergency and extreme urgency) mau tidak mau, penerima lisensi harus menyetujui ketentuan dalam perjanjian baku tersebut. Maka sangat penting perlindungan hukum bagi para pihak yang terlibat dalam perjanjian lisensi paten dalam program alih teknologi di Indonesia, khususnya perlindungan hukum terhadap penerima lisensi (licencee) karena dalam praktiknya kedudukan penerima lisensi (licencee) perlu 
diperhatikan kembali oleh pemerintah sebab menimbang persyaratan pengalihan teknologi ditetapkan oleh pihak pemberi lisensi (licencor).

Berdasarkan uraian diatas, penulis berpendapat bahwa salah satu tujuan dari hukum adalah memberikan kepastian hukum dan perlindungan hukum terhadap subjek hukum. Oleh karena itu, perlindungan hukum terhadap subjek-subjek hukum harus diwujudkan dalam bentuk adanya suatu kepastian hukum. Selanjutnya hukum dapat melindungi hak dan kewajiban setiap individu dalam melakukan tindakan hukum. Berdasarkan kondisi ini, penulis tertarik untuk melakukan sebuah penelitian. Adapun rumusan masalah yang diangkat adalah: (1) Bagaimana pengaturan perjanjian lisensi paten menurut hukum positif di Indonesia? (2)Bagaimana perlindungan hukum terhadap penerima lisensi paten dalam penggunaan klausul kontrak baku? Tujuan penelitian untuk mengetahui pengaturan perjanjian lisensi paten menurut hukum positif di Indonesia dan perlindungan hukum terhadap penerima lisensi paten dalam penggunaan klausul kontrak baku.

\section{METODE PENELITIAN}

Metode penelitian yang dipergunakan dalam penelitian ini yaitu penelitian hukum normatif yaitu metode yang di gunakan dengan cara pengkajian suatu bahan-bahan hukum dan sumber-sumber bacaan hukum. Tipe penelitian yang dipergunakan yaitu pendekatan dari perundang-undangan yang memiliki hubungan dengan judul yang dibuat dan pendekatan konseptual, dimana pendekatan ini bermula dari suatu konsep sudut pandang dan doktin yang berkembang dan diyakini dalam ilmu hukum guna memberikan ide, konsep, pandangan yang relevan dengan suatu permasalahan yang ada (Marzuki, 2013). Sumber hukum yang dipergunakan dalam penelitian ini yaitu bahan hukum primer adalah bahan hukum yang memiliki sifat otoritas yaitu hasil suatu tindakan yang dilakukan oleh lembaga yang memiliki kewenangan yaitu Kitab Undang-undang Hukum Perdata, Undang-Undang Nomor 3 Tahun 2016 tentang Paten, Undang-Undang Nomor 7 Tahun 1994 tentang Pengesahan Agreement Establishing The Word Trade Organization (Persetujuan pembentukan organisasi perdagangan dunia, Peraturan Pemerintah Nomor 36 Tahun 2018 Pencatatan Perjanjian Lisensi Kekayaan Intelektual, Peraturan Pemerintah Nomor 20 tahun 2005 tentang Alih Teknologi Kekayaan Intelektual serta Hasil Kegiatan Penelitian dan Pengembangan Oleh Perguruan Tinggi dan Lembaga Penelitian dan Pengembangan (Marzuki, 2005). Bahan hukum sekunder yaitu bahan hukum yang didapkan dari mengkaji kepustakaan, yakni dengan buku-buku hukum, jurnal ilmiah dan juga sumber bacaan di internet yang berterkaitan dengan pengaturan lisensi paten dalam alih teknologi.

\section{HASIL PENELITIAN DAN PEMBAHASAN}

\section{Pengaturan Perjanjian Lisensi Paten Menurut Hukum Positif di Indonesia}

Lisensi dari HAKI (hak atas kekayaan intelektual) menurut August yaitu suatu cara agar dapat meningkatkan suatu angka terciptanya peluang usaha dalam pasar dalam negeri maupun luar negeri untuk mendapatkan keuntungan yang lebih banyak lagi, pemilik dari Hak Kekayaan Intelektual dapat memberikan lisensi kepada pihak lain (Sulasno, 2019). Secara yuridis lisensi dapat diterjemahkan sebagai suatu kontrak diantara pemberi lisensi (Licencor) dengan pihak penerima lisensi (Licencee) di mana pemberi lisensi dengan suatu pembayaran dan dalam situasi tertentu memberikan izin kepada pihak penerima lisensi mempergunakan suatu egara kekayaan intelektualnya (intellectual property rights) (Soemantoro, 1986).Terhadap jenis-jenis lisensi dapat dipilah menjadi beberapa kelompok yaitu dari suatu objek lisensi, sifat lisensi, cakupan lingkup suatu lisensi itu sendiri, dan cara terjadinya lisensi. Menurut Lee dan Davidson, memberikan perbedaan menjadi 2 (dua) jenis lisensi yaitu khusus dan tidak khusus (Lee \& Davidson, 1990).

Dalam bahasa Indonesia, perbandingan kata yang dapat diartikan sebagai lisensi wajib yang dalam Pasal 82 UU Paten disebutkan bahwa lisensi-wajib merupakan lisensi untuk melaksanakan Paten yang diberikan dan diperbolehkan dengan adanya putusan pihak berwenang yang dalam hal ini adalah menteri atas dasar suatu pengajuan permohonan. Perkembangan pengaturan lisensi paten secara historis, pengaturan tentang Hak Kekayaan Intelektual di Indonesia dimulai sejak tahun 1840-an atau tepatnya pada masa penjajahan Belanda.

Pada tahun 1888, Indonesia atau yang pada saat itu dikenal dengan nama Netherlands EastIndies telah masuk ke dalam anggota Paris Convention for the Protection of Industrial Property atau lebih dikenal dengan nama Konvensi Paris. Dalam konvensi paris ini, diperkenalkan istilah 
Compulsory Licenses (lisensi wajib) terdapat dalam Article 5 Bagian A. Mengingat pengaturan Konvensi Paris (Paris Convention for the Protetion of Industrial Property) sifatnya terlalu umum kemudian dibentuklah perjanjian yang secara khusus mengatur paten antara lain: Eropan Convention Relating to the Formalities Required to Patent Application, Eropan Convention for International Classification of Patent, Eropan Patent Convention (EPC) the Community Patent Convention (CPC). Berawal dari konversi Paris tersebutlah Indonesia yang mewarisi aturan dari pemerintah Belanda di dalam perundang-undangan di dalamnya meratifikasi lisensi ke dalam perundang-undangan Hak Kekayaan Intelektual. Pada Tanggal 13 Oktober 1989 Dewan Perwakilan Rakyat menyetujui RUU tentang Paten, yang selanjutnya disahkan menjadi UU No. 6 tahun 1989 (UU Paten 1989) oleh Presiden RI pada Tanggal 1 November 1989. Dalam jangka waktu tahun 1989 sampai dengan Undang-undang paten yang berlaku sekarang ini sudah mengalami beberapa kali perubahan.

Perjanjian lisensi paten pada dasarnya tunduk dan mengacu pada ketentuan perjanjian yang dianut oleh Negara Indonesia pada KUH-Per. Dalam perkembangan dunia secara konsep keilmuan hukum perjanjian, membuat perjanjian tunduk dengan syarat sahnya dan asas-asas yang melekat pada hukum perjanjian. Namun dalam suatu pembentukan perjanjian lisensi paten, dikarenakan keadaan sosial ekonomi yang semakin berkembang dan melaju sangat cepat maka ditentukanlah suatu syaratsyarat perjanjian lisensi secara sepihak. Dari hal tersebut maka pada jaman sekarang ini lisensi yang dibuat dalam perjanjian memiliki bentuk perjanjian yang bersifat baku atau standard contract yang dibuat oleh Pemberi Lisensi (Sulasno, 2019). Adapun suatu kontrak baku pada saat ini banyak diterapkan dalam dunia bisnis karena beberapa alasan-alasan yaitu alasan secara teknis, sosial ekonomi, efisiensi waktu. Dalam Pasal 76 UU Paten disebutkan bahwa pemegang Paten memiliki hak untuk memberikan Lisensi kepada orang lainnya berdasarkan perjanjian Lisensi baik secara khusus maupun tidak khusus untuk melakukan perbuatan. Suatu perjanjian Lisensi tidak diperbolehkan mengandung unsur yang dapat membuat rugi kepentingan nasional Indonesia atau memuat pembatasan yang menghambat kemampuan bangsa Indonesia dalam melakukan pengalihan, penguasaan, dan pengembangan teknologi. Hal ini beiringan dengan dibentuknya suatu Peraturan Pemerintah Nomor 36 Tahun 2018 Pencatatan Perjanjian Lisensi Kekayaan Intelektual yang menyebutkan bahwa suatu perjanjian lisensi membuat kerugian Negara, menghalangi perkembangan bangsa Indonesia untuk mengembangkan kemampuannya, mengakibatkan persaingan tidak sehat, dan juga bertentangan dengan peraturan perundang-undangan.

\section{Perlindungan Hukum terhadap Penerima Lisensi Paten}

Perjanjian Lisensi Paten yang dilihat dasarnya adalah suatu perjanjian seperti pada umumnya, maka perjanjian lisensi paten merupakan perjanjian antara kedua belah pihak yaitu penerima lisensi (licencee) dan pemberi lisensi (licencor) yang dimana kedua belah pihak mengikuti ketentuan perjanjian yang berlaku didalam Kitab Undang-undang Hukum Perdata di Indonesia. Salah satu adalah pada pasal 1338 KUH-Per yang dimana bahwa seluruh perjanjian yang dibuat oleh para pihak berlaku mengikat sebagai undang-undang bagi mereka yang membuatnya. Persetujuan itu tidak dapat diubah kembali selain adanya kesepakatan antara kedua belah pihak, atau karena suatu alasan yang ditentukan oleh suatu peraturan yang mengatur. Persetujuan yang dilakukan harus dilaksanakan dengan itikad baik.

Kedua belah pihak dalam menjalankan perjanjian tunduk pada asas-asas hukum perjanjian yang berlaku di Indonesia antara lain:

1. Asas Kebebasan Berkontrak

Pada dasarnya kebebasan berkontrak bersumber atas teori hukum alam yang melihat bahwa manusia merupakan mahluk yang rasional dan memiliki intelektualitas, yang dapat melakukan sesuatu dengan berdasarkan keinginannya. Kebebasan berkontak memberikan jaminan kebebasan kepada setiap individu untuk secara bebas dalam beberapa hal yang berkaitan (Miru, 2011). dengan ruang lingkupnya yaitu: kebebasan untuk membuat atau tidak suatu perjanjian, kebebasan memilih dengan siapa hendak ingin membuat perjanjian, kebebasan untuk memilih klausa perjanjian yang akan dibuat, kebebasan untuk menentukan suatu objek yang akan diperjanjiakan, kebebasan untuk menentukan suatu bentuk perjanjian baik itu akan tertulis maupun lisan, kebebasan untuk syarat-syarat suatu perjanjian, termasuk kebebasan mengesampingkan atau melaksanakan ketentuan undang-undang yang bersifat pilihan (Harianto, 2016). 


\section{Asas konsensualisme}

Asas konsensualisme, yang artinya perjanjian itu lahir (terjadi) semenjak saat terciptanya kata sepakat dari kedua belah pihak (Styawati, 2008). Sepakat menurut Kamus Besar Bahasa Indonesia yangberarti "Setuju". Kesepakatan merupakan suatu kesesuaian antara kehendak dan dituangkan dalam pernyataan yang akan dibuat oleh para pihak dalam suatu perjanjian. Asas konsensualisme menyatakan bahwa perjanjian lahir karena sudah adanya kesepakatan antara kedua belah pihak.

\section{Asas Pacta Sunt Servanda}

Asas Pacta Sunt Servanda atau disebut pula dengan asas kepastian hukum (Salim, 2019). Dengan adanya kesepakatan antara kedua belah pihak dalam suatu perjanjian, hal tersebut menimbulkan kekuatan mengingat yang menimbulkan akibat dan hubungan hukum antara kedua belah pihak.

4. Asas Itikad Baik

Asas Itikad Baik sebagai salah satu yang disepakati dan disetujui oleh kedua belah pihak, penyelenggaraan suatu prestasi dalam setiap perjanjian harus di hormati sepenuhnya sesuai kehendak para pihak (Muljadi \& Widjaja, 2014).

Dalam suatu perjanjian lisensi dikarenakan menggunakan suatu kontrak baku maka berpotensi membawa ketidakseimbangan para pihak. Adapun kelemahan-kelemahan dalam suatu proses pengalihan teknologi dalam perjanjian lisensi, yang juga dapat dirugikan si penerima teknologi (licensee). Karena beberapa perjanjian pemberi lisensi (lisensor) menggunakan klausulklausul dalam suatu perjanjiannya sebagai berikut (Mubarok, 2007): klausula dimana masing-masing pihak yakni pemegang lisensi dan lisensor saling mengembangkan teknologi yang dilisensi ,pemegang lisensi berkewajiban agar membeli bahan mentah, komponen, peralatan bagi keperluan produksinya dari pemberi lisensi (lisensor), klausul yang dengan sengaja dapat membatasi pemegang lisensi untuk mengenalkan dan menjual produk-produknya.

Secara teoritikal hukum perjanjian, untuk membuat perjanjian mengacu terhadap asas-asas dan syarat sahnya yang terdapat di dalam peraturan perundang-undangan. Akan tetapi, dikarenakan kondisi sosial ekonomi maka ditetapkanlah syarat-syarat perjanjian tersebut secara sepihak. Adapun perlindungan hukum terhadap penerima lisensi paten (licencee) dapat dibagi menjadi dua tahapan yaitu perlindungan hukum preventif, dimana terdapat faktor-faktor yang harus diperhatikan yaitu faktor peraturan dan juga pengawasan pemerintah. Sedangkan perlindungan hukum represif yaitu dengan suatu perjanjian lisensi dengan standard contrak atau kontrak baku yang dipergunakan oleh pemberi lisensi paten (licencor) kepada penerima lisensi paten (licencee), jika melanggar suatu syarat subjektif dalam pembuatan perjanjian lisensi paten maka akan menimbulkan akibat hukum dapat dibatalkan (vernietigbaarheid) sesuai ketentuan yang berlaku yang dimana arti dari dapat dibatalkan merupakan dapat dimintakan suatu pembatalan oleh salah satu pihak ke dalam sidang pengadilan. Sedangkan apabila melanggar suatu syarat objektif akan menimbulkan akibat hukum batal demi hukum (Neitigbaarheid), dimana batal demi hukum dimaksudkan bahwa suatu perjanjian lisensi paten yang telah dibuat dianggap tidak pernah ada sebelumnya.

\section{SIMPULAN DAN SARAN}

Berdasarkan beberapa uraian-uraian dan pembahasan yang telah dipaparkan pada hasil penelitian yang dilakukan maka dapat ditarik beberapa kesimpulan bahwa Pengaturan Perjanjian Lisensi Paten dalam hukum positif di Indonesia dapat dilihat bahwa lisensi dalam hak kekayaan intektual khususnya paten di atur dalam UU Paten yang dimana paten merupakan suatu hak khusus yang diberikan oleh negara pada penemu atas hasil temuannya dalam bidang teknologi dengan jangka waktu tertentu melaksanakan sendiri temuannya tersebut atau memberikan pengesahan kepada pihak lain untuk melaksanakannya. Pemberian lisensi paten telah diatur dalam Pasal 76 No. 13 Tahun 2016 tentang UU Paten.

Secara yuridis lisensi diartikan sebagai suatu kontrak antara pemberi lisensi (licencor) kepada pihak penerima lisensi (licencee). Suatu perjanjian lisensi paten harus mengacu kepada ketentuan perundang-undangan yang dianut oleh Negara. Perlindungan hukum terhadap penerima lisensi paten dapat dibagi menjadi perlindungan hukum preventif dan perlindungan hukum represif. Perlindungan hukum preventif meliputi faktor peraturan dan juga faktor pengawasan pemerintah. Sedangkan perlindungan hukum refpresif menegaskan pada suatu perjanjian lisensi paten yang melanggar suatu ketentuan perundang-undangan ditindak secara tegas degan tidak dapatnya berlaku suatu perjanjian 
lisensi tersebut ataupun perjanjian lisensi tersebut dinyatakan batal. Hal ini mengacu pada syarat sahnya dan pembatalan perjanjian sesuai dengan perundang-undangan di Indonesia.

\section{DAFTAR PUSTAKA}

Harianto, D. (2016). Asas Kebebasan Berkontrak: Problematika Penerapannya dalam Kontrak Baku antara Konsumen dengan Pelaku Usaha. Jurnal Hukum Samudra Keadilan, 11(2), 145-156.

Julianto, D., \& Marta, Z. (2019). Pengaruh Pengeluaran Pemerintah dan Investasi Swasta terhadap Perkembangan Industri Pariwisata di Sumatera Barat. Menara Ilmu, 8(2), 16-24.

Lee, L. C., \& Davidson, S. (1990). Introduction to Intellectual Property Law. Butterworth.

Marzuki, P. M. (2005). Penelitian Hukum. PT. Kencana Prenada Media Group.

Marzuki, P. M. (2013). Penelitian Hukum (8th ed.). Kencana Prenada Media Group.

Miru, A. (2011). Prinsip-prinsip Perlindungan Konsumen. Rajawali Pers.

Mubarok, R. (2007). Alih Teknologi melalui Perjanjian Lisensi Kaitannya dengan Undang-Undang Nomor 14 Tahun 2001 tentang Paten. Jurnal Ilmiah Dan Dinamika Masyarakat, 5(1).

Muhtarom, M. (2014). Asas-Asas Hukum Perjanjian: Suatu Landasan dalam Membuat Kontrak. Suhuf, 26(1), 48-56.

Muljadi, K., \& Widjaja, G. (2014). Perikatan yang Lahir dari Perjanjian. PT. Raja Grafindo Persada.

Salim, H. S. (2019). Hukum Kontak Teori dan Teknik Penyusunan Kotrak. Sinar Grafika.

Soemantoro. (1986). Hukum Ekonomi (Soemantoro (ed.)). UI-Press.

Styawati, N. K. A. (2008). Tesis Perjanjian Standar yang Mengandung Klausa Eksemsi Dalam Perjanjian Kredit Bank di Kaji dari Undang-undang No.8 Tahun 1999 tentang Perlindungan Konsumen (Studi Kasus Putusan No.206/PDT.G/2005/PN.DPS-Bali). Universitas Gadjah Mada.

Sulasno, S. (2019). Lisensi Hak Kekayaan Intelektual (HKI) dalam Perspektif Hukum Perjanjian di Indonesia. ADIL: Jurnal Hukum, 3(2), 352-379.

Udiana, I. M. (2011). Rekonstruksi Pengaturan Penyelesaian Sengketa Penanaman Modal Asing. Udayana University Press. 